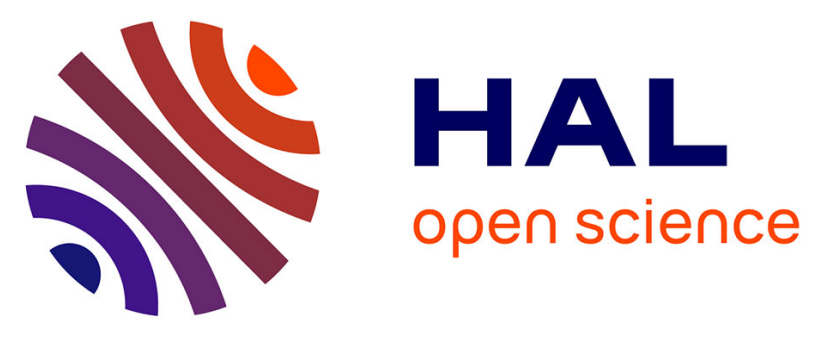

\title{
Diversity of nematophagous fungi in Moroccan olive nurseries: Highlighting prey-predator interactions and efficient strains against root-knot nematodes
}

Mohamed Ait Hamza, Hicham Lakhtar, Hafssa Tazi, Abdelmajid Moukhli, Odile Fossati-Gaschignard, Lucie Miche, Sevastianos Roussos, Zahra Ferji, Abdelhamid El Mousadik, Thierry Mateille, et al.

\section{To cite this version:}

Mohamed Ait Hamza, Hicham Lakhtar, Hafssa Tazi, Abdelmajid Moukhli, Odile Fossati-Gaschignard, et al.. Diversity of nematophagous fungi in Moroccan olive nurseries: Highlighting prey-predator interactions and efficient strains against root-knot nematodes. Biological Control, 2017, 114, pp.1423. 10.1016/j.biocontrol.2017.07.011 . hal-01681583

\section{HAL Id: hal-01681583 https://hal.science/hal-01681583}

Submitted on 23 Apr 2018

HAL is a multi-disciplinary open access archive for the deposit and dissemination of scientific research documents, whether they are published or not. The documents may come from teaching and research institutions in France or abroad, or from public or private research centers.
L'archive ouverte pluridisciplinaire HAL, est destinée au dépôt et à la diffusion de documents scientifiques de niveau recherche, publiés ou non, émanant des établissements d'enseignement et de recherche français ou étrangers, des laboratoires publics ou privés. 
1 Diversity of nematophagous fungi in Moroccan olive nurseries: Highlighting prey-predator

2 interactions and efficient strains against root-knot nematodes.

3

4 Mohamed AÏT HAMZA ${ }^{1,4}$, Hicham LAKHTAR ${ }^{2}$, Hafssa TAZI ${ }^{2}$, Abdelmajid MOUKHLI ${ }^{3}$, Odile 5 FOSSATI-GASCHIGNARD ${ }^{4}$, Lucie MICHÉ 5 , Sebastianos ROUSSOS ${ }^{5}$, Zahra FERJI ${ }^{6}$, Abdelhamid

${ }^{1}$ Université Ibn Zohr, Faculté des Sciences d'Agadir, Laboratoire LBVRN, BP 8106, 80000 Agadir,

8 Morocco.

$9 \quad{ }^{2}$ Université Ibn Zohr, Faculté des Sciences d'Agadir, Laboratoire LBMPV, BP 8106, 80000 Agadir, 10 Morocco.

${ }^{3}$ INRA, CRRA, BP 513, Menara, Marrakech, Morocco.

${ }^{4}$ IRD, UMR CBGP, 755 Avenue du Campus Agropolis, CS30016, 34988 Montferrier-sur-Lez Cedex, 13 France.

$14{ }^{5}$ IRD, UMR IMBE, Faculté des Sciences Saint Jérôme, Case 421, 13397 Marseille Cedex 20, France.

$15{ }^{6}$ Institut Agronomique et Vétérinaire Hassan II, Campus d'Agadir, Département de Protection des Plantes, BP 18/S, 80000 Agadir, Morocco. 


\section{Abstract}

Plant-parasitic nematodes are major pests in agriculture. Microbial antagonists such as nematophagous fungi are of great interest for developing alternative biocontrol strategies to replace nematicide use. This study aims to isolate, identify and assess the diversity and the in vitro predatory activity of nematophagous fungi from various olive nurseries in Morocco. A total of 305 soil samples were collected in 25 nurseries in Moroccan olive-producing areas (Jbala, Guerouane, Haouz and Souss). Seventy-three pure fungal strains from nematophagous fungi were recovered from nursery substrates infested with root-knot nematodes. Diversity indices showed that fungi were more numerous in southern regions, whereas fungal communities were more numerically alike in northern regions, partly depending on the occurrence of root-knot nematodes. One fungal strain, Talaromyces assiutensis, killed all Meloidogyne javanica juveniles during in vitro predation tests. Orbiliaceae (Arthrobotrys spp., Drechslerella brochopaga, Monacrosporium spp.) trapped 50 to $80 \%$ of juveniles. Purpureocillium and Trichoderma species killed 30 to $50 \%$ of juveniles. The diversity of nematophagous communities could be affected by the north-south climate gradient of Morocco, by their nematode prey expansion, and, to a lesser extent, by the habitat origin of the substrates used. Talaromyces assiutensis was the most efficient nematophagous species against $M$. javanica. The use of native nematophagous fungi is a promising alternative strategy for nematode control in olive nurseries and to prevent nematode introduction into olive orchards.

Keywords: Culture substrate, Ecology, Fungal antagonists, Olive tree, Root-knot nematode. 
The olive tree (Olea europaea L.) is widely distributed throughout the Mediterranean Basin. In Morocco alone, the olive-growing area is estimated at 650,000 ha and produces 120,000 tons of oil and 150,000 tons of table olives per year (Ministry of Agricultural and Marine Fisheries, 2009). Planting material comes from several nurseries distributed throughout the olive-producing areas and olive plantlets are certified free of pathogens (e.g., Verticillium dahlia) and parasites (e.g., plant-parasitic nematodes). Nevertheless, standard health practices are not applied in all nurseries and seasonal and informal nurseries coexist.

Several plant-parasitic nematode species (PPN) have been found to be associated with olive trees (Castillo et al., 2010; Ali et al., 2014; Hamza et al., 2015), including root-knot nematodes (RKN, Meloidogyne spp.) that were shown to impact olive growth (Afshar et al., 2014). RKN have been reported to be major pests on olive trees, mainly in nurseries where irrigation conditions are favorable to their multiplication (Nico et al., 2002; Sanei and Okhovvat, 2011). Moreover, most RKN infestations in olive orchards result from contaminated plant material produced in uncertified nurseries (Nico et al., 2002). To protect nurseries, vegetative propagation of olive is a crucial step to prevent plant pest dispersal. While some industrial olive-producing countries use synthetic substrates to cultivate olive trees, other countries use more traditional olive cultivation techniques, planting roots in soil substrates. In countries that have implemented large-scale planting programs (e.g., 1,220,000 ha in the Morocco Green Plan, 2015), the "nursery risk" is a concern, with two main consequences: (i) the weakening of olive plants before their transplantation into orchards; and (ii) the introduction of pathogens into orchards. The nematode risk is now controlled in nurseries, either by multiplication of resistant varieties (Palomares-Rius et al., 2012) or by inoculating microbial antagonists in the substrates, such as mycorrhizae (Castillo et al., 2006). 
Thus, in view of the large-scale development of olive cultivation in Morocco, sanitization of the substrates must be a priority. Some previous studies highlighted that certain substrates can be suppressive depending on their composition, either because of microbial antagonisms or of toxicity. For example, the addition of forest residues provides organic matter that could contribute to PPN suppression by increasing soil microflora (Rodriguez-Kabana, 1987). Composted dry cork, especially in nurseries, could be effective for $M$. incognita suppression due to the toxicity of the products released (e.g., ammonia, phenolic compounds) (Nico et al., 2004). Moreover, the introduction of microbial antagonists into substrates would strengthen the sustainability of preventive techniques and help introduce biocontrol agents into orchards.

Microbial antagonists of PPN include nematophagous fungi (NF), raising expectations for their use in integrated pest management (Waller, 2006; Larsen, 2006; Maingi et al., 2006). These fungi act by antibiosis, parasitism or predation (Imerglik, 1981; Gaspard and Mankau, 1986). Fungi trap nematodes using adhesive networks or buttons. Some NF capture their prey with constrictor rings before strangling them and others with hyphae networks that produce sticky compounds. The specific enzymes then digest the nematodes. Recognition and attachment of the mycelium to the nematode cuticle are mainly due to compatible glycoproteins such as lectins (Nordbring-Hertz et al., 2006).

Nevertheless, edaphic factors such as soil $\mathrm{pH}$, temperature, moisture and structure influence their efficiency (Brown and Kerry, 1987). Fungal diversity can increase in stressed or polluted sites (Korol et al., 1994) in order to adapt to changing environments (West et al., 1999). In Arthrobotrys oligospora, genetic diversity varies according to environmental conditions. Their strains could generate recombinant genotypes by crossing with native strains, thus enhancing their environmental adaptability and parasitizing ability (Zhang et al., 2013). 
However, the reproductive strategies of fungi like A. oligospora can change depending on the population. According to Cook (1993), the search for microorganisms from the rhizospheric soil of a specific crop could lead to the isolation of effective antagonists against pathogens that could be adapted to the plant species as well as to particular environmental conditions.

Considering that olive seedlings in Morocco are generally cultivated in non-sanitized substrates consisting of soil material from various habitat origins, the recovery of native NF from substrates may be of great interest in order to develop RKN biocontrol agents adapted to nursery conditions. In this context, this work aims to (i) evaluate the nematode populations in substrates from olive nurseries in Morocco; (ii) isolate and characterize NF able to control RKN (Meloidogyne spp.); (iii) determine the occurrence and diversity of nematode-associated $\mathrm{NF}$ and discuss prey-predator interactions; and (iv) investigate their in vitro predatory potential towards M. javanica juveniles and eggs, and their usefulness as biocontrol agents for olive protection in nurseries and in orchards.

\section{Materials and methods}

\section{1. $\quad$ Site description and olive plantlet sampling}

Soil samples were collected in spring 2013 and 2014 from 25 commercial olive nurseries located in the main olive-producing areas in Morocco (Fig. 1 and Table 1): the Jbala, Guerouane, Haouz and Souss regions. The nurseries were selected for their plantlet production, the cultivars grown and the rearing substrates used.

Olive plants are grown in 2-to-3 liter plastic bags filled with solid substrates from different sources (alluvial sandy soils, forest soils, loamy open-field soils) supplemented with different proportions of sand, peat fertilizer and animal manure. Plants are first grown in plastic greenhouses and then outside. They are watered by sprinklers and fertilized with Osmocote® 
(Everris Company $\left.{ }^{\mathrm{TM}}\right)$.

In each nursery and for each variety, five olive plantlets (Olea europaea subsp. europaea) growing in plastic bags were sampled. Information about the origin and the preparation of the growth substrates and about the cultivars was recorded. A total of 305 olive plantlets were collected and maintained in the laboratory and kept under greenhouse conditions (12 h light at $25^{\circ} \mathrm{C} ; 12 \mathrm{~h}$ dark at $\left.20^{\circ} \mathrm{C}\right)$.

\section{2. $\quad$ Nematode extraction and quantification}

A $250-\mathrm{cm}^{3}$ substrate subsample was removed from the rhizosphere of each olive plantlet and used for nematode extraction using the Oostenbrink (1960) elutriation procedure (ISO 236114). Free-living nematodes (FLN) and plant-parasitic nematodes (PPN), which specifically exhibit a stylet for plant-cell feeding, were enumerated in $5-\mathrm{cm}^{3}$ counting chambers (Merny and Luc, 1969) under a stereomicroscope (×60 magnification). Nematode population levels were expressed as the number of individuals per $\mathrm{dm}^{3}$ of fresh substrate. Among PPN, rootknot nematodes belonging to the Meloidogyne genus (Mai and Mullin, 1996) were counted.

\subsection{Isolation of nematophagous fungi}

NF were isolated from solid substrate samples infested with RKN using the soil sprinkling technique (Duddington, 1955) as modified by Santos et al. (1991). The direct soil powdering on media was preferable to the modified Baermann method (aqueous soil suspensions) (Hernández-Chavarría and Avendaño, 2001) because it provided more concentrated material for fungal isolation. Moreover, isolation success was increased by sprinkling cold soil (stored at $4^{\circ} \mathrm{C}$ ) on culture medium at 37 to $40^{\circ} \mathrm{C}$ (Davet and Rouxel, 2000). Substrate aliquots from each olive plantlet were spread on a tray to be air-dried. One gram was then sprinkled on the surface of Petri dishes containing water-agar (WA 2\% w/v) supplemented with antibiotics ( $0.05 \%$ streptomycin-sulphate and $0.05 \%$ chloramphenicol). Three replicates were done per olive plantlet. A 1-mL suspension containing approximately 3,000 M. javanica second-stage 
juveniles (J2) and 10 eggs produced in the laboratory was added as fungal bait, according to

144 the procedure used by Drechsler (1941). The Petri dishes were sealed with Parafilm and

145 incubated at room temperature $\left(20-27^{\circ} \mathrm{C}\right)$ in darkness for two months. Petri dishes were

146 examined daily during the first week of incubation and weekly thereafter. Fungi that had

147 developed were isolated under a microscope (x60 magnification). Conidia or pieces of agar

148 bearing either an NF mycelium or an infected nematode were transferred onto Petri dishes

149 containing Corn Meal Agar (CMA) or Potato Dextrose Agar (PDA) supplemented with 150 antibiotics $(0.05 \%$ streptomycin-sulphate and $0.05 \%$ chloramphenicol). The fungi were

151 transferred to a new culture medium plate for purification after reaching full growth. Pure

152 cultures were maintained on PDA or CMA plates at $4^{\circ} \mathrm{C}$ in darkness for a maximum of six

153 months.

2.4. $\quad$ Morphological and molecular characterization of the fungi

The initial identification of the fungi was based on colony morphology and microscopic characteristics. Slide sub-cultures from pure NF cultures were observed under a dissecting microscope (up to x100 magnification). Genera and species were assigned according to specialized morpho-taxonomical keys (Cooke and Dickinson, 1965; Haard, 1968; Barron, 1977; Yu et al., 2014; Philip, 2002).

Sequence analyses of the ITS (internal transcribed spacer) region in the ribosomal RNA gene cluster were performed to confirm the identity of the NF species. The DNA was extracted from 50-200 mg of mycelium (fresh weight) using the NucleoSpin ${ }^{\circledR}$ Plant II Genomic DNA Purification Kit (Promega ${ }^{\circledR}$ ) according to the manufacturer's instructions. PCR reaction was performed according to the method described by White et al. (1990): the ITS rDNA gene cluster was amplified using the primers ITS1 (5'TCC GTA GGT GAA CCT GCG G 3') and ITS4 (5'TCC TCC GCT TAT TGA TAT GC 3'). The PCR amplification was carried out using the GeneAmpR PCR System 9700 (Applied Biosystems ${ }^{\circledR}$ ). Twenty $\mu$ l of reaction 
mixture contained $2 \mu \mathrm{l}(10 \mathrm{ng})$ of template DNA, $1 \mu \mathrm{l}$ of each ITS1 and ITS4 primer (10 $\mathrm{mM}), 4 \mu \mathrm{l}$ PCR buffer, $2.4 \mu 1 \mathrm{MgCl}_{2}(25 \mathrm{mM}), 0.6 \mu \mathrm{l}$ dNTPs $(10 \mathrm{mM}), 0.1 \mu 1 \mathrm{BSA}(0.1$ $\mathrm{mg} / \mathrm{ml}$ ) and 0.2 units of $\mathrm{GoTaq}^{\circledR}$ DNA polymerase.

PCR cycling conditions consisted of an initial denaturation step at $94^{\circ} \mathrm{C}$ for $3 \mathrm{~min}, 35$ cycles of denaturation at $94^{\circ} \mathrm{C}$ for $30 \mathrm{sec}$, annealing at $55^{\circ} \mathrm{C}$ for $30 \mathrm{sec}$ and elongation at $72^{\circ} \mathrm{C}$ for 10 min. PCR products were checked for length, quality and quantity by agarose gel electrophoresis $(1 \%(\mathrm{w} / \mathrm{v})$ in $0.5 \mathrm{x}$ Tris-Acetate-EDTA (TAE).

PCR products were sequenced from both ends by Eurofins MWG GmbH (Ebersberg, Germany), using the same ITS primers. CHROMAS LITE v2.1.1 (Technelysium Pty Ltd.) software was used to edit and assemble DNA sequences. BLAST similarity searches were performed in the non-redundant nucleotide database of GenBank (Altschul et al., 1997) to identify/verify species or genus affiliation of collected isolates. Sequences were aligned with ITS sequences of reference strains obtained from GenBank. Subsequently, the alignment was used to perform the phylogenetic tree with PHYLOGENY.FR (Dereeper et al., 2008) and Mega 6 (Tamura et al., 2007) using the neighbor-joining method (Saitou and Nei, 1987) and the Jukes-Cantor correct distance model (Jukes and Cantor, 1969). The phylogenetic tree was obtained from data using one of three equally parsimonious trees through 1,000 bootstrap replicates (Felsenstein, 1985) with a heuristic search consisting of 10 random-addition replicates for each bootstrap replicate.

\subsection{Diversity of the fungal communities}

Four diversity indices were calculated to assess NF communities: total number of isolates found in each soil sample $(N)$; richness ( $S=$ number of species in the community); ShannonWiener local diversity index $\left(H^{\prime}=-\Sigma\left(\mathrm{p}_{\mathrm{i}} \cdot \ln \mathrm{p}_{\mathrm{i}}\right)\right.$, where $\mathrm{p}_{\mathrm{i}}$ is the proportion of isolates with the species $i)$; and evenness $\left(\mathrm{E}=H^{\prime} / \ln (S)\right)$, which quantifies the numerical equality of populations in communities. 
An olive population of the RKN M. javanica (detected in $72 \%$ of the nurseries surveyed and dominant in orchards) (Ali et al., 2016) was reared on RKN-susceptible tomato (cv. Roma) in a greenhouse $\left(12 \mathrm{~h} \mathrm{light}\right.$ at $25^{\circ} \mathrm{C} ; 12 \mathrm{~h}$ dark at $\left.20^{\circ} \mathrm{C}\right)$. Fungal strains that exhibited trapping, adhesive or encysting organs were sub-cultured on WA in 9-cm-diameter Petri dishes. One week later, 100 second-stage juveniles (J2) of $M$. javanica (the only free form in the soil) were washed five times with $0.05 \%$ streptomycin-sulfate in sterilized distilled water, introduced into each fungal sub-culture and maintained at $25^{\circ} \mathrm{C}$ in darkness. Three Petri dishes per fungal strain were considered as replicates. Fungal predation structures were observed and predated/dead nematodes were counted after four days under a microscope (x100 magnification). Similar procedures were used to study predation of M. javanica eggs by specialized egg parasites such as Paecilomyces and Pochonia fungi. Dishes with nematodes but without fungi were considered as control replicates.

Mean values were analyzed by one-way ANOVA and Kruskall-Wallis tests were used for all pair-wise multiple comparisons. NF community patterns were explored through a Principal Component Analysis (PCA) of the diversity indices. Region grouping was tested using Monte-Carlo tests on PCA eigenvalues (randtest, ade4). Calculations were performed and graphics prepared using R language (readxl, base and ade4 packages) (R Development Core Team, 2011; Chessel et al., 2004; Dray and Dufour, 2007, Wickham, 2016), with a level of significance $=0.05)$. A rarefaction regression was used to analyze the dependence between root-knot nematodes (Meloidogyne spp.) and nematophagous fungi.

\section{Results}

\subsection{Nematofauna}


A non-significant gradient was present in plant-parasitic-nematodes (PPN), with a north-south increase of the population levels (Table 2). A parallel significant gradient was revealed in root-knot nematodes (RKN, Meloidogyne spp.). Free-living nematodes (FLN) were three times more abundant in the Souss olive nurseries than in the other regions. The ratios between FLN and PPN were different between all regions, the highest ratio being found in the Souss region.

\section{2. $\quad$ Nematophagous species and phylogenetic diversity}

Several fungal isolates were recovered from the 305 soil samples examined. Observation of characteristic conidia and traps around dead M. javanica juveniles revealed 149 soil samples positive for NF. Morphological identification using microculture techniques revealed $73 \mathrm{NF}$ strains belonging to 11 genera.

In order to confirm the characterization of the fungal strains, the ITS regions of rDNA were sequenced. Five species (Catenaria anguillulae, Nematoctonus leiosporus, Haptoglossa heterospora, Dactylaria sp. and Monacrosporium microphoides) were excluded from the sequencing because it was not possible to purify them. The BLAST test showed that the ITS sequences of all sequenced strains were at least $99 \%$ similar to the corresponding GenBank reference sequences (Table 3). The phylogenetic analysis including ITS sequences of the Moroccan NF isolates and 16 reference sequences of identified close relatives revealed five distinct clusters (Figs. 2 A-E): Purpureocillium lilacinum, Trichoderma, Fusarium oxysporum, Talaromyces and Arthrobotrys-Dreschslerella-Monacrosporium (family Orbiliaceae).

The combination of the morphological and the molecular analyses established that the isolated NF belonged to 19 species, eight families and six orders (Table 4). Arthrobotrys was the most diversified genus with five species, followed by Trichoderma (three species). The abundance of fungal species was low (less than five strains per species) except for Paecilomyces lilacinus 
that represented 36 strains (50\% of the strains). Half of the $P$. lilacinus strains detected were isolated from the Souss region, and then gradually decreased northwards (12 in Haouz, four in Guerouane, two in Jbala). Arthrobotrys brochopaga, A. scaphoides, Monacrosporium thaumasium, P. lilacinus, F. oxysporum, T. harzianum, T. asperellum and T. longibrachiatum were encountered in the four regions. A. oligospora, Dactylaria sp., Haptoglossa heterospora, Monacrosporium microscaphoides, Nematoctunus leiosporus and Talaromyces assiutensis were very rare (one isolate in one region). All the fungal species except A. oligospora were detected in the Souss region. Only eight species were detected in the Jbala region. The Guerouane and Haouz regions hosted 11 and 12 species, respectively.

\subsection{Diversity patterns}

Because of their scarcity (only one nursery surveyed), the substrate samples from the Jbala region were excluded from the dataset prior to running analyses. Richness $(S)$ and local diversity $\left(H^{\prime}\right)$ were correlated to the PC1 axis, while the PC2 axis was related to numbers $(N)$ and to evenness $(E)$ of fungal isolates on its positive and negative sides, respectively (Fig. 3A). Region grouping was significant in the whole analysis and on the PC2 axis (Fig. 3B). Isolates were more numerous in the Souss region, whereas fungal communities were more numerically alike in the Guerouane region. The Haouz region had lower NF richness and diversity (non-significant PC1 coordinates). Indices were affected by the north-south distribution of the nurseries (Figs. 3C-3E-3D).

The percentage of samples with NF was lower in the Haouz region than elsewhere (Table 5). Both trapping and endoparasitic fungi occurred more often in the Souss region than in the others regions, and no endoparasitic species were found in the Jbala region.

The rarefaction regression established between the occurrence of RKN (Meloidogyne spp.) and the occurrence of NF (Fig. 4) indicated a significant positive correlation, regardless of the region sampled. 
3.4. In vitro efficiency of the nematophagous strains

269

270

271

272

NF were distinguished according to their ability to kill $M$. javanica J2s (Fig. 5). Talaromyces assiutensis killed all juveniles in all replicates. The Orbiliaceae species (Arthrobotrys spp., Dreschlerella spp., Monacrosporium spp.) were efficient against $M$. javanica since they trap 50 to $80 \%$ of the J2s using adhesives networks, buttons, constricting rings and hyphae networks. Paecilomyces and Trichoderma strains killed 30 to $50 \%$ of the J2s. Fusarium oxysporum strains were less efficient (less than $20 \%$ of dead J2s). P. lilacinus and $P$. chlamydosporia strains infected all the $M$. javanica eggs.

\section{Discussion}

Our first objective was to evaluate nematode populations in substrates from olive nurseries. In all regions of Morocco, PPN abundance was greater than 1.4 nematodes $/ \mathrm{dm}^{3}$ of soil and FLN abundance greater than 1.9. As a comparison, Hamza et al. (2015) found 0.2 to $5.1 \mathrm{PPN} / \mathrm{dm}^{3}$ of soil and 0.3 to $4.3 \mathrm{FLN} / \mathrm{dm}^{3}$ of soil in 23 Souss and Haouz orchards. It can thus be hypothesized that the multiplication of nematode populations may be boosted by acidity and by hydrophilic and non-degraded organic matter (Neher and Olson, 1999; Manlay et al., 2000; Ou et al., 2005; McSorley, 2011). The usual dominance of FLN in olive soils could be due to the origin of organic substrates (mountain soils, peat and manure) used in most nurseries (Castillo et al., 2006). FLN are known to dominate in soil substrates not yet used for agriculture (Hillocks, 1997). The FLN dominance in the Souss region, one of the most intensively cultured areas in Morocco, was thus unexpected.

The FLN/PPN ratios were balanced in all regions except in the Souss where most of the soil substrates come from cropped areas (vegetables and citrus fruits). Because of the sandy texture of the soils in the Souss region, culture practices include high amounts of organic matter (especially cattle manure or tomato leaf compost), leading to an increase in FLN 
populations and to a decrease in PPN populations because organic matter is unsuitable for PPN (Clark et al., 1998; Hominick, 1999; Hu and Qi, 2010). These mechanisms may explain the FLN/PPN ratio that is twice as high in the Souss region compared to the other regions The high percentages of RKN (Meloidogyne spp.) in Souss olive nurseries may be justified by the dominance throughout the area of vegetable crops that are highly susceptible to these nematodes (Sikora and Fernandez, 2005; Netscher, 1970).

Our second objective was to isolate and characterize nematophagous fungi able to control RKN (Meloidogyne spp.). The success of fungal strain isolation from soils may be correlated with soil temperature, moisture and organic matter content (Akhtar and Malik, 2000; Cayrol et al., 1992). The greatest difficulty encountered was in isolating pure NF strains because of the rapid growth of plant-pathogenic fungi and saprophytes such as Fusarium, Alternaria and Aspergillus species. An increased $\mathrm{pH}$ of culture media may prevent the development of other microorganisms (Gardner et al., 2000). Moreover, we found that direct cold soil powdering on hot media $\left(37\right.$ to $40^{\circ} \mathrm{C}$ ), like in Kelly et al., (2009), was preferable to aqueous soil suspensions because it provided more concentrated fungal material (Davet and Rouxel, 2000; HernándezChavarría and Avendaño, 2001). Dispersing agents were avoided because they inhibited the growth of some NF strains (Davet and Rouxel, 2000).

This survey provided native NF from Morocco for the first time. The large number of soil samples (305) allowed the detection of numerous NF strains, whereas former studies revealed one strain at best (Bridge and Spooner, 2001). The strains detected as nematophagous possessed different modes of action: adhesive networks, constricting rings, hyphal tips, adhesive conidia and mycotoxins (Imerglik, 1981; Gaspard and Mankau, 1986). Despite this, ITS rDNA sequences could not be used to identify some NF strains due to their small size (Pochonia chlamydosporia, for example), BLAST tests were useful to confirm the morphological characterization of other strains. The integrated taxonomical analysis 
(morphological and molecular) of the NF provided a pool of 28 strains belonging to 19 species. The phylogenic analysis revealed that the ITS rDNA gene was able to distinguish species in a genus group (such as Trichoderma) but did not fully discriminate species belonging to the family Orbiliaceae, indicating the taxonomic proximity of Dreschlerella, Arthrobotrys and Monacrosporium species. Therefore, an integrative molecular analysis should be developed with other molecular markers (White et al., 1990) in order to improve NF identification.

Our third objective was to determine the occurrence and diversity of nematode-associated NF. All NF species except A. oligospora were detected in the Souss region where they were more dominant than in the other regions. This high diversity of NF might be due to the multiple habitat origins of the components (mountain, riverbank and field soils, cattle manure, plant compost, etc.) used to make substrates for root olive plantlets. We hypothesize that the microbial richness detected in the Souss region corresponds to the high endemic plant diversity characteristic of the Macaronesian region (Médail and Diadema, 2009; Msanda et al., 2005). This could also be due to higher organic matter concentration in the soils (i.e., saprophytic substrate for fungi that induce the formation and the activity of trapping 1994; Singh et al., 2012).

The number of NF isolates globally increased southwards, whereas evenness decreased (PCA2 axis). It is known that different thermal regimes affect soil microbial diversity (Bridge and Spooner, 2001). The absence of seasonality and the higher minimum temperatures in the Souss region may explain these developments where irrigation counteracts the arid to semiarid climate. The high occurrence of NF and the high evenness detected in the Guerouane region may be linked to a more continental climate. More than half of the $36 P$. lilacinus strains came from the Souss region where the NF richness was the highest but the evenness 
the lowest. In a restricted soil area, the abundance of $P$. lilacinus may cause the rarity of the other species. For a constant number of species, maximal diversity is achieved when species have an even distribution. The Haouz, Jbala and Guerouane regions were characterized by less PPN and FLN than in the Souss region, explaining the lower NF richness in those regions.

Our fourth objective was to investigate the in vitro predation of the NF against $M$. javanica juveniles and eggs. Talaromyces assiutensis (strain UIZFSA-31), whose nematode predation was previously unknown, killed all the $M$. javanica juveniles in four days. The mode of action of $T$. assiutensis remains unknown but we hypothesize that the strain may produce specific mycotoxins. In vitro trapping tests prove that the Orbiliaceae species (Arthrobotrys spp., Dreschlerella spp., Monacrosporium spp.) were able to trap M. javanica juveniles. The predatory capacity of $A$. oligospora was similar to data found in the literature (Singh et al., 2012). The mechanisms involved during predation are well known (Imerglik, 1981; Gaspard and Mankau, 1986). Recognition and attachment of the mycelium to the cuticle of the RKN juvenile is mainly due to compatible glycoproteins, e.g., lectins (Duponnois et al., 1996). Trichoderma species are recognizsed as control agents against nematodes, and various mechanisms have been proposed to explain nematode killing, including antibiosis and enzymatic hydrolysis (Sivan and Chet, 1992; Elad, 2000). Thomas (1996) demonstrated direct interactions between $T$. harzianum and the cyst nematode Globodera rostochiensis: the fungus penetrated eggs in the cysts, leading to the death of the juveniles (Sharon et al., 2001). Precise information on the mechanisms involved is very limited and this misunderstanding has hindered the selection of active strains and the development of improved biocontrol methods. Paecilomyces lilacinus and Pochonia chlamydosporia are especially powerful nematode egg parasites (Cayrol et al., 1982; Irving and Kerry, 1986), which could explain the relatively low predation rate obtained on juveniles. These species can also act on the 
movement of infested nematode juveniles via a paralytic toxin (Cayrol et al., 1989), purified and identified as acetic acid by Djian et al. (1991). This molecule is abundantly produced during fungal growth in liquid medium (ibid). Fusarium oxysporum strains, well-known plant pathogens, exhibited lower predation rates, but some studies revealed that they are partly able to kill nematodes by producing toxic sulfuric heterocycles (fusarenone and moniliformine) (Ciancio et al., 1988; Cayrol et al., 1992).

Moreover, the significant co-occurrence of RKN and NF highlighted by the rarefaction curve suggests a close interaction between prey (nematodes) and predators (fungi) in olive nurseries, as described by Lotka-Volterra models (Barbosa and Castellanos, 2005), probably because of parasitism induction by nematodes (Jansson and Nordbring-Hertz, 1980). Even though the diversity of the NF detected in the four regions was variable at species and population levels, we may expect symmetric dynamics (Marrow and Cannings, 1993) due to possible co-evolutionary processes involved between nematodes and fungi. Such processes occur between competitive organisms in an ever-changing environment, as described by the “Red Queen” hypothesis (Van Valen, 1973; Dawkins and Krebs, 1979).

\section{Conclusion}

Olive nursery solid substrates are infested with PPN, including Meloidogyne species. Various predatory fungi were able to kill RKN. Consequently, before selecting NF strains as candidates for biocontrol, studies must be extended to a wider range of Meloidogyne species and populations present on olive trees in Morocco in order to verify their specificity.

Indigenous NF strains were recovered from different substrates (different habitats), making it possible to undertake more research in order to understand the specificity of prey-predator interactions with more diverse PPN species. Predation efficiency in different cropping systems and in varied soil environments should also be explored in the future. 


\section{Acknowledgements}

395

396

397

400

401

402

403

404

405

406

407

408

409

410

411

412

413

414

415

416

This research was supported by a Ph.D. grant from the "Institut de Recherche pour le Développement" (Marseille, France). It was also funded by the PESTOLIVE project: Contribution of olive history for the management of soil-borne parasites in the Mediterranean Basin (ARIMNet action KBBE 219262), and by the BIONEMAR project: Development of fungal bionematicides for organic production in Morocco (PHC-Toubkal action 054/SVS/13).

\section{Conflict of interest statement}

We declare that we have no conflict of interest.

\section{References}

Afshar, F.J., Sasanelli, N., Hosseininejad, S., Maafi, Z.T., 2014. Effects of the root-knot nematodes Meloidogyne incognita and M. javanica on olive plants growth in glasshouse conditions. Helminthologia 51, 46-52.

Akhtar, M. and Malik, A., 2000. Roles of organic soil amendments and soil organisms in the biological control of plant-parasitic nematodes: a review. Bioresource Technology 74, $35-47$.

Ali, N., Chapuis, E., Tavoillot, J. and Mateille, T., 2014. Plant-parasitic nematodes associated with olive tree (Olea europaea L.) with a focus on the Mediterranean Basin: A review. Comptes Rendus Biologies 337, 423-442.

Ali, N., Tavoillot, J., Chapuis, E. and Mateille, T., 2016. Trend to explain the distribution of root-knot nematodes Meloidogyne spp. associated with olive trees in Morocco. Agriculture, Ecosystems and Environment 225, 22-32. 
Altschul, S. F., Madden, T. L., Schäffer, A. A., Zhang, J., Zhang, Z., Miller, W., \& Lipman, D. J., 1997. Gapped BLAST and PSI-BLAST: a new generation of protein database search programs. Nucleic acids research, 25 17, 3389-3402.

Barbosa, P. and Castellanos, I., 2005. Ecology of predator-prey interactions: New York: Oxford University Press.

Barron, G.L., 1977. The nematode-destroying fungi: Canadian Biological Publications Ltd.

Bridge, P. and Spooner, B., 2001. Soil fungi: diversity and detection. Plant and Soil 232, 147154.

Brown, R.H. and Kerry, B.R., 1987. Principles and practice of nematode control in crops: Academic Press Australia.

Castillo, P., Nico, A.I., Azcón-Aguilar, C., Del Río Rincón, C., Calvet, C. and Jiménez-Díaz, R.M., 2006. Protection of olive planting stocks against parasitism of root-knot nematodes by arbuscular mycorrhizal fungi. Plant Pathology 55, 705-713.

Castillo, P., Nico, A.I., Navas-Cortés, J.A., Landa, B.B., Jiménez-Díaz, R.M. and Vovlas, N., 2010. Plant-parasitic nematodes attacking olive trees and their management. Plant Disease 94, 148-162.

Cayrol, J., VELASQUEZ-Dominguez, M. and Levaux, P., 1982. Etude préliminaire sur les possibilités d'utilisation des champignons parasites comme agents de lutte biologique. EPPO Bulletin 12, 497-503.

Cayrol, J.-C., Djian, C. and Pijarowski, L., 1989. Study of the nematicidal properties of the culture filtrate of the nematophagous fungus Paecilomyces lilacinus. Revue de Nematologie 12, 331-336.

Cayrol, J.-C., Djian-Caporalino, C. and Panchaud-Mattei, E., 1992. La lutte biologique contre les nématodes phytoparasites. Courrier de la Cellule Environnement INRA 17, 31-44. 
Chessel, D., Dufour, A. and Thioulouse, J., 2004. The ade4 package. I. One-table methods. $R$ News 4: 5-10.

Ciancio, A., Logrieco, A., Lamberti, F. and Bottalico, A., 1988. Nematicidal effects of some Fusarium toxins. Nematologia Mediterranea 16, 137-138.

Clark, M., Ferris, H., Klonsky, K., Lanini, W., Van Bruggen, A. and Zalom, F., 1998. Agronomic, economic, and environmental comparison of pest management in conventional and alternative tomato and corn systems in northern California. Agriculture, Ecosystems \& Environment 68, 51-71.

Cook R.J., 1993. Making greater use of introduced microorganisms for biological control of plant pathogens. Annual Revue of Phytopathology 31, 53-80.

Cooke, R. and Dickinson, C., 1965. Nematode-trapping species of Dactylella and Monacrosporium. Transactions of the British Mycological Society 48, 621-629.

Davet, P. and Rouxel, F., 2000. Detection and isolation of soil fungi. Science Publisher Inc., Enfield and Plymouth.

Dawkins, R. and Krebs, J.R., 1979. Arms races between and within species. Proceedings of the Royal Society of London B: Biological Sciences 205, 489-511.

Den Belder, E. and Jansen, E., 1994. Capture of plant-parasitic nematodes by an adhesive hyphae forming isolate of Arthrobotrys oligospora and some other nematode-trapping fungi. Nematologica 40, 423-437.

Dereeper, A., Guignon, V., Blanc, G., Audic, S., Buffet, S., Chevenet, F., Dufayard, J.-F., Guindon, S., Lefort, V. and Lescot, M., 2008. Phylogeny. fr: robust phylogenetic analysis for the non-specialist. Nucleic Acids Research 36, W465-W469.

Djian, C., Pijarowski, L., Ponchet, M., Arpin, N. and Favre-Bonvin, J., 1991. Acetic acid: a selective nematicidal metabolite from culture filtrates of Paecilomyces lilacinus (Thom) Samson and Trichoderma longibrachiatum Rifai. Nematologica 37, 101-112. 
Dray, S. and Dufour, A.B., 2007. The ade4 package: implementing the duality diagram for ecologists. Journal of Statistical Software 22, 1-20.

Drechsler, C., 1941. Some hyphomycetes parasitic on free-living terricokms nematodes. Phytopathology 31, 773-802.

Duddington, C., 1955. Notes on the technique of handling predacious fungi. Transactions of the British Mycological Society 38, 97-103.

Duponnois, R., Mateille, T., Sene, V., Sawadogo, A. and Fargette, M, 1996. Effect of different west african species and strains of Arthrobotrys nematophagous fungi on Meloidogyne species. Entomophaga 41, 475-483.

Elad, Y., 2000. Biological control of foliar pathogens by means of Trichoderma harzianum and potential modes of action. Crop Protection 19, 709-714.

Felsenstein, J., 1985. Confidence intervals on phylogenetics:an approach using bootstrap. Evolution 39:783-791.

Gardner, K., Wiebe, M.G., Gillespie, A.T. and Trinci, A.P., 2000. Production of chlamydospores of the nematode-trapping Duddingtonia flagrans in shake flask culture. Mycological Research 104, 205-209.

Gaspard, J. and Mankau, R., 1986; Nematophagous fungi associated with Tylenchulus semipenetrans and the citrus rhizosphere. Nematologica 32, 359-363.

Haard, K., 1968. Taxonomic studies on the genus Arthrobotrys Corda. Mycologia 60, 11401159.

Hamza, M.A., Ferji, Z., Ali, N., Tavoillot, J., Chapuis, E., El Oualkadi, A., Moukhli, A., Khadari, B., Boubaker, H., Lakhtar, H., Roussos, S., Mateille, T. and El Mousadik, A., 2015. Plant-parasitic nematodes associated with olive tree in Southern Morocco. International Journal of Agriculture and Biology 17, 719-726. http://DOI: 10.17957/IJAB/14.0004. 
Hernández-Chavarría, F. and Avendaño, L., 2001. A simple modification of the Baermann method for diagnosis of strongyloidiasis. Memórias do Instituto Oswaldo Cruz 96, 805-807.

Hillocks, R.J. and Waller, J.M., 1997. Associations between soilborne pathogens and other soil-inhabiting microorganisms. In: Soilborne diseases of tropical crops. Waller, J.M. and Hillocks, R.J. (Ed.), CAB International, Wallingford, pp.351-364.

Hominick, B., 1999. Nematodes. In Proceedings of the International Workshop on Tropical Soil Biology: Opportunities and Challenges for African Agriculture, Nairobi, 16-19 March.

Hu, C. and Qi, Y., 2010. Abundance and diversity of soil nematodes as influenced by different types of organic manure. Helminthologia 47, 58-66.

Imerglik, L., 1981. Recherches préliminaires sur la spécificité du piégage des nématodes par des hyphomycètes prédateurs. DAA Protection des cultures ENSA Montpellier.

Irving, F. and Kerry, B., 1986. Variation between strains of the nematophagous fungus, Verticillium chlamydosporium Goddard. II. Factors affecting parasitism of cyst nematode eggs. Nematologica 32, 474-485.

ISO 23611-4, 2007. Soil quality - Sampling of soil invertebrates - Part 4: Sampling, extraction and identification of soil-inhabiting nematodes. ISO, $20 \mathrm{pp}$.

Jansson, H-B. and Nordbring-Hertz, B., 1980. Interactions between nematophagous fungi and plant-parasitic nematodes: attraction, induction of trap formation and capture. Nematologica 26, 383-389.

Jukes, T.H. and Cantor, C.R., 1969. Evolution of protein molecules. Mammalian Protein Metabolism 3, 132. 
Kelly, P., Good, B., Hanrahan, J., Fitzpatrick, R. and de Waal, T., 2009. Screening for the presence of nematophagous fungi collected from Irish sheep pastures. Veterinary Parasitology 165, 345-349.

Korol, A., Preygel, I. and Preygel, S., 1994. Recombination variability and evolution. Chapman Hall, London.

Larsen, M., 2006. Biological control of nematodes parasites in sheep. Journal of Animal Science 84, E133-E139.

Mai, W.F., and Mullin P.G., 1996. Plant-parasitic nematodes: a pictorial key to genera, 5th edn. Comstock Publishing Associates, New-York.

Maingi, N., Krecek, R. and Biljon, N., 2006. Control of gastrointestinal nematodes in goats on pastures in South Africa using nematophagous fungi Duddingtonia flagrans and selective anthelmintic treatments. Veterinary Parasitololgy 138, 328-336.

Manlay, R.J., Cadet, P., Thioulouse, J. and Chotte, J.-L., 2000. Relationships between abiotic and biotic soil properties during fallow periods in the sudanian zone of Senegal. Applied Soil Ecology 14, 89-101.

Marrow, P. and Cannings, C., 1993. Evolutionary instability in predator-prey systems. Journal of Theoretical Biology 160, 135-150.

McSorley, R., 2011. Effect of disturbances on trophic groups in soil nematode assemblages. Nematology 13, 553-559.

Médail, F. and Diadema, K., 2009. Glacial refugia influence plant diversity patterns in the Mediterranean Basin. Journal of Biogeography 36, 1333-1345.

Merny, G. and Luc, M., 1969. Les techniques d'échantillonnage des peuplements de nématodes dans le sol. In: Lamotte M., Boulière F. (Eds.). Problèmes d'écologie, l'échantillonnage des peuplements animaux dans les milieux terrestres, Masson, Paris, pp.257-292. 
Ministry of Agriculture and marine Fischeries, 2009. Plan vert du Maroc: de la stratégie à l'action du Maroc.

Msanda, F., El Aboudi, A. and Peltier, J.-P., 2005. Biodiversité et biogéographie de l'arganeraie marocaine. Cahiers Agricultures 14, 357-364.

Neher, D.A. and Olson, R.K., 1999. Nematode communities in soils of four farm cropping management systems. Pedobiologia 43, 430-438.

Netscher, C., 1970. Les nématodes parasites des cultures maraîchères au Sénégal. Cahiers ORSTOM, Série Biologie 11, 209-229.

Nico, A.I., Jiménez-Díaz, R.M. and Castillo, P., 2004. Control of root-knot nematodes by composted agro-industrial wastes in potting mixtures. Crop Protection 23, 581-587.

Nico, A.I., Rapoport, H.F., Jiménez-Díaz, R.M. and Castillo, P., 2002. Incidence and population density of plant-parasitic nematodes associated with olive planting stocks at nurseries in southern Spain. Plant Disease 86, 1075-1079.

Nordbring- Hertz, B., Jansson, H.B. and Tunlid, A., 2006. Nematophagous fungi. In: Encyclopedia Life Sciences. John Wiley \& Sons, Ltd, 1-11.

Oostenbrink, M., 1960. Estimating nematode populations by some selected methods. Nematology 6.

Ou, W., Liang, W., Jiang, Y., Li, Q. and Wen, D., 2005. Vertical distribution of soil nematodes under different land use types in an aquic brown soil. Pedobiologia 49, 139-148.

Palomares-Rius, J.E., Castillo, P., Montes-Borrego, M., Müller, H. and Landa, B.B., 2012. Nematode community populations in the rhizosphere of cultivated olive differs according to the plant genotype. Soil Biology and Biochemistry 45, 168-171.

Philip, J., 2002. Nematophagous fungi: Guide by Philip Jacobs, BRICVersion online. Accessed on: June/2008. Available at http://www.biological-research.com/. 
R Development Core Team, 2011. R: A language and environment for statistical computing. R Foundation for Statistical Computing, Vienna, Austria. ISBN 3-900051-07-0. http://www.R-project.org/.

Rodriguez-Kabana, R., Morgan-Jones, G. and Chet, I., 1987. Biological control of nematodes: soil amendments and microbial antagonists. Plant and Soil 100, 237-247.

Saitou, N. and Nei, M., 1987. The neighbor-joining method: a new method for reconstructing phylogenetic trees. Molecular Biology and Evolution 4 , 406-425.

Sanei, S. and Okhovvat, S., 2011. Incidence of plant-parasitic nematodes associated with olive planting stocks at nurseries in northern Iran. International Journal of Applied Science and Technology 1, 79-82.

Santos, M., Ferraz, S. and Muchovej, J., 1991. Detection and ecology of nematophagous fungi from Brazil soils. Nematologia Brasileira 15, 121-134.

Sharon, E., Bar-Eyal, M., Chet, I., Herrera-Estrella, A., Kleifeld, O. and Spiegel, Y., 2001. Biological control of the root-knot nematode Meloidogyne javanica by Trichoderma harzianum. Phytopathology 91, 687-693.

Sikora, R.A. and Fernandez, E., 2005. Nematode parasites of vegetables. In: Plant parasitic nematodes in subtropical and tropical agriculture, Luc, M., Sikora, R.A. and Bridge, J. (Eds.). CABI Publishing, Wallingford, pp.319-392.

Singh, U.B., Sahu, A., Singh, R., Singh, D.P., Meena, K.K., Srivastava, J. and Manna, M. (2012) Evaluation of biocontrol potential of Arthrobotrys oligospora against Meloidogyne graminicola and Rhizoctonia solani in Rice (Oryza sativa L.). Biological Control 60, 262-270.

Sivan, A. and Chet, I., 1992. Microbial control of plant diseases. Environmental Microbiology, 335-354. 
Stirling, G.R., 1991. Biological control of plant parasitic nematodes: progress, problems and prospects: CAB International Wallingford, pp282.

Tamura, K., Dudley, J., Nei, M. and Kumar, S., 2007. MEGA4: molecular evolutionary genetics analysis (MEGA) software version 4.0. Molecular Biology and Evolution 24, 1596-1599.

Thomas, B., 1996. Studies on the parasitism of Globodera rostochiensis by Trichoderma harzianum using low temperature scanning electron microscopy. Afroasian Journal of Nematology 6, 117-122.

Van Valen, L., 1973. A new evolutionary law. Evolutionary Theory 1, 1-30.

Waller, P., 2006. From discovery to development: current industry perspectives fo the development on novel methods of helminth control in livestock. Veterinary Parasitology 139: 1-14.

West, G.B., Brown, J.H. and Enquist, B.J., 1999. The fourth dimension of life: fractal geometry and allometric scaling of organisms. Science 284, 1677-1679.

White, T.J., Bruns, T., Lee, S. and Taylor, J., 1990. Amplification and direct sequencing of fungal ribosomal RNA genes for phylogenetics. PCR protocols: a guide to methods and applications 18, 315-322.

Wickham, H., 2016. readxl: Read Excel Files. R package version 0.1.1. https://CRAN.Rproject.org/package=readxl/.

Yu, Z., Mo, M., Zhang, Y. and Zhang, K.-Q., 2014. Taxonomy of nematode-trapping fungi from Orbiliaceae, Ascomycota. In: Nematode-trapping fungi. Zhang, K.Q. and Hyde, K.D. (Eds.), Springer, Dordrecht Netherlands, pp.41-210.

Zhang, Y., Qiao, M., Xu, J., Cao, Y., Zhang, K.Q. and Yu, Z.F., 2013. Genetic diversity and recombination in natural populations of the nematode-trapping fungus Arthrobotrys oligospora from China. Ecology and Evolution 3, 312-325. 


\section{Legends for figures and tables}

Figure 1 Distribution of the olive nurseries surveyed in Morocco. See Table 1 for more information.

Figure 2 Neighbor-joining tree inferred from ITS rDNA sequences of the nematophagous fungi isolated (in bold) and their closest GenBank matches (with accession numbers). Bootstrap support values (1000 replicates) are provided as a percentage at the corresponding nodes when $>50$. A to $\mathrm{E}=$ high similarity between phylogenetic groups

Figure 3 Diversity indices of the nematophagous fungus communities. (A) PCA loading plot for the diversity indices in soil samples $(\mathrm{N}=$ a total number of isolates; $\mathrm{S}=$ species richness; $H^{\prime}=$ Shannon-Wiener diversity; $E=$ species evenness). (B) Score plot for the samples according to the region $(\mathrm{J}=\mathrm{Jbala} ; \mathrm{G}=$ Guerouane; $\mathrm{H}=$ Haouz; $\mathrm{S}=\mathrm{Souss}) .(\mathrm{C}, \mathrm{D}, \mathrm{E}) N, H^{\prime}$ and $E$ boxplots ( $a-c$ indicate significant groups, $P<0.05$ ).

Figure 4 Rarefaction curve for root-knot nematodes (Meloidogyne spp.) and nematophagous fungi detected in the olive nurseries according to the regions $(\mathrm{J}=\mathrm{Jbala} ; \mathrm{G}=$ Guerouane; $\mathrm{H}=$ Haouz; S = Souss).

Figure 5. In vitro efficiency of nematophagous fungal strains: percentage of dead M. javanica juveniles ( $a-e$ indicate significant groups, $P<0.05$ ).

Table 1 Location and characteristics of the Moroccan olive nurseries surveyed. Number of samples for each cultivar in each geographic region.

Table 2 Average density (number of nematodes $/ \mathrm{dm}^{3}$ of soil) of plant-parasitic nematodes (PPN) and free-living nematodes (FLN), percentages of samples infested with root-knot nematodes (RKN) and FLN/PPN ratios ( $a$ - $d$ indicate significant groups, $P<0.05)$.

Table 3 BLAST results of ITS rDNA sequences of the nematophagous fungi isolated.

Table 4 Nematophagous fungi associated with the Moroccan olive nurseries surveyed.

Table 5 Functional diversity of the nematophagous fungi ( $a$ - $d$ indicate significant groups, $P<$ 
$639 \quad 0.05)$. 
641 Location and characteristics of the Moroccan olive nurseries. Number of samples for each cultivar in each geographic region.

\begin{tabular}{|c|c|c|c|c|c|c|c|}
\hline $\begin{array}{l}\text { Geographic } \\
\text { region }\end{array}$ & Location & Climate & City & $\begin{array}{c}\text { No. of } \\
\text { nurseries }\end{array}$ & $\begin{array}{c}\text { Main habitat origin } \\
\text { of the substrates }\end{array}$ & Olive cultivar & No. of samples \\
\hline \multirow[t]{3}{*}{ Jbala } & \multirow{3}{*}{$\begin{array}{c}\text { South-west face } \\
\text { of the Rif Mountains }\end{array}$} & \multirow{3}{*}{$\begin{array}{l}\text { Sub humid climate, } \\
\text { temperature from }-6^{\circ} \\
\text { to } 32^{\circ} \mathrm{C}\end{array}$} & \multirow[t]{3}{*}{ Ouazzane } & \multirow[t]{3}{*}{1} & \multirow{3}{*}{$\begin{array}{c}\text { Clay marls, } \\
\text { sand, forest soil } \\
\text { and topsoil }\end{array}$} & Picholine marocaine & 5 \\
\hline & & & & & & Haouzia & 5 \\
\hline & & & & & & Menara & 5 \\
\hline \multirow[t]{7}{*}{ Guerouane } & \multirow{7}{*}{$\begin{array}{l}\text { Sais Plateau, between } \\
\text { the Middle Atlas } \\
\text { to the south and the Rif } \\
\text { Mountains to the north }\end{array}$} & \multirow{7}{*}{$\begin{array}{l}\text { More continental } \\
\text { climate, temperature } \\
\text { from }-10^{\circ} \text { to } 45^{\circ} \mathrm{C}\end{array}$} & \multirow[t]{7}{*}{ Meknes } & \multirow[t]{7}{*}{4} & \multirow{7}{*}{$\begin{array}{l}\text { Yellow sand, } \\
\text { topsoil, } \\
\text { mature manure } \\
\text { and local } \\
\text { compost }\end{array}$} & Picholine marocaine & 15 \\
\hline & & & & & & Haouzia & 20 \\
\hline & & & & & & Menara & 20 \\
\hline & & & & & & Arbequina & 5 \\
\hline & & & & & & Arbosana & 5 \\
\hline & & & & & & Picual & 10 \\
\hline & & & & & & Picholine Languedoc & 5 \\
\hline \multirow[t]{11}{*}{ Haouz } & \multirow{11}{*}{$\begin{array}{c}\text { Northern slope } \\
\text { of the High Atlas } \\
\text { Mountains }\end{array}$} & \multirow{11}{*}{$\begin{array}{l}\text { Semiarid climate, } \\
\text { average temperatures } \\
\text { from }-6^{\circ} \text { to } 49.6^{\circ} \mathrm{C}\end{array}$} & \multirow[t]{6}{*}{ Marrakech } & \multirow[t]{6}{*}{5} & \multirow{6}{*}{$\begin{array}{l}\text { Clay marls, } \\
\text { sand, } \\
\text { forest soil, } \\
\text { mountain soil } \\
\text { and topsoil }\end{array}$} & Picholine marocaine & 25 \\
\hline & & & & & & Arbequina & 10 \\
\hline & & & & & & Haouzia & 25 \\
\hline & & & & & & Menara & 25 \\
\hline & & & & & & Picholine Languedoc & 10 \\
\hline & & & & & & Arbosana & 5 \\
\hline & & & \multirow[t]{4}{*}{ El Kelaa des Sraghna } & \multirow[t]{4}{*}{3} & \multirow{4}{*}{$\begin{array}{l}\text { Forest soil } \\
\text { and topsoil }\end{array}$} & Picholine marocaine & 15 \\
\hline & & & & & & Picholine Languedoc & 15 \\
\hline & & & & & & Menara & 10 \\
\hline & & & & & & Haouzia & 10 \\
\hline & & & Sidi Abdellah Ghiat & 1 & Soil, clay and sand & Picholine marocaine & 5 \\
\hline \multirow[t]{5}{*}{ Souss } & \multirow{5}{*}{$\begin{array}{c}\text { On the southern slope } \\
\text { of the High Atlas } \\
\text { Mountains }\end{array}$} & \multirow{5}{*}{$\begin{array}{l}\text { Arid constant climate, } \\
\text { sunshine }>340 \text { days a } \\
\text { year, average } \\
\text { temperatures from } 14^{\circ} \\
\text { to } 25^{\circ} \mathrm{C}\end{array}$} & \multirow[t]{3}{*}{ Agadir } & \multirow[t]{3}{*}{8} & \multirow{3}{*}{$\begin{array}{l}\text { Sand, topsoil } \\
\text { and peat moss }\end{array}$} & Picholine marocaine & 15 \\
\hline & & & & & & Haouzia & 20 \\
\hline & & & & & & Menara & 5 \\
\hline & & & Khmiss Ait Amira & 2 & $\begin{array}{l}\text { Topsoil, peat } \\
\text { and manure }\end{array}$ & Picholine marocaine & 10 \\
\hline & & & Biougra & 1 & Peat, soil and perlite & Menara & 5 \\
\hline
\end{tabular}


643 Average density (number of nematodes $/ \mathrm{dm}^{3}$ of soil) of plant-parasitic nematodes (PPN) and

644 free-living nematodes (FLN), percentages of samples infested with root-knot nematodes

$645(\mathrm{RKN})$ and FLN/PPN ratios $(a-d$ indicate significant groups, $P<0.05)$.

\begin{tabular}{lcccc}
\hline Regions & $\begin{array}{c}\text { No. of PPN } \\
\left(/ \mathrm{dm}^{3} \text { of soil }\right)\end{array}$ & $\begin{array}{c}\text { \% of samples } \\
\text { infested with } \\
\text { RKN }\end{array}$ & $\begin{array}{c}\text { No. of FLN } \\
\left(/ \mathrm{dm}^{3} \text { of soil }\right)\end{array}$ & FLN/PPN \\
\hline Jbala & 1,441 & $16.0 d$ & $2,220 b$ & $1.54 b$ \\
Guerouane & 1,527 & $20.0 c$ & $1,914 b$ & $1.25 c$ \\
Haouz & 2,003 & $58.1 b$ & $2,081 b$ & $1.04 d$ \\
Souss & 2,395 & $76.4 a$ & $6,194 a$ & $2.59 a$ \\
\hline P-value & 0.153 & 0.000 & 0.000 & 0.000
\end{tabular}

646 Table 3

647 BLAST results of ITS rDNA sequences of the nematophagous fungi isolated.

\begin{tabular}{|c|c|c|c|c|c|}
\hline \multirow[t]{2}{*}{ Strains } & \multicolumn{4}{|l|}{ GenBank reference strains } & \multirow{2}{*}{$\begin{array}{c}\text { Maximum } \\
\text { similarity }(\%)\end{array}$} \\
\hline & Species & Strain & $\begin{array}{l}\text { GenBank } \\
\text { accession no. }\end{array}$ & $\begin{array}{l}\text { Number of } \\
\text { nucleotides (bp) }\end{array}$ & \\
\hline$U I Z F S A-1$ & Paecilomyces lilacinus & MY683 & GU980015 & 541 & 99 \\
\hline UIZFSA-2 & Paecilomyce slilacinus & MY683 & GU980015 & 541 & 99 \\
\hline UIZFSA-3 & Purpureocillium lilacinum & NPF-4 & KP308838 & 565 & 99 \\
\hline UIZFSA-5 & Purpureocillium lilacinum & DF58 & KT582081 & 713 & 99 \\
\hline UIZFSA-6 & Purpureocillium lilacinum & MSEF24 & KT310947 & 540 & 99 \\
\hline UIZFSA-12 & Purpureocillium lilacinum & E303 & KJ540087 & 540 & 99 \\
\hline$U I Z F S A-13$ & Arthrobotrys thaumasia & isolate 111 & EU977532 & 561 & 100 \\
\hline UIZFSA-15 & Purpureocillium lilacinum & SBTPl-001 & KF766523 & 625 & 99 \\
\hline UIZFSA-18 & Arthrobotrys scaphoides & CBS 226.52 & KF494006 & 565 & 99 \\
\hline$U I Z F S A-20$ & Fusarium oxysporum & K9 & JF807396 & 491 & 99 \\
\hline$U I Z F S A-21$ & Fusarium oxysporum & A2-3 & KT876690 & 510 & 100 \\
\hline$U I Z F S A-22$ & Fusarium oxysporum & DSCF2 & AB470914 & 509 & 100 \\
\hline$U I Z F S A-23$ & Fusarium oxysporum & Z11 & EF611086 & 540 & 99 \\
\hline UIZFSA-24 & Trichoderma asperellum & OTPT7 & KC551811 & 581 & 100 \\
\hline$U I Z F S A-24$ & Trichoderma asperellum & SI14 & KJ432865 & 548 & 100 \\
\hline$U I Z F S A-25$ & Trichoderma asperellum & OTPT7 & KC551811 & 546 & 100 \\
\hline UIZFSA-26 & Trichoderma asperellum & SVPP-3 & KU215915 & 549 & 100 \\
\hline$U I Z F S A-27$ & Trichoderma harzianum & SZMC 20965 & KP316410 & 567 & 100 \\
\hline UIZFSA-30 & Trichoderma asperellum & CPCRI-TD-11 & KT445769 & 594 & 99 \\
\hline$U I Z F S A-31$ & Talaromyces assiutensis & ph721 & KF147920 & 537 & 99 \\
\hline UIZFSA-35 & Trichoderma longibrachiatum & $Y-14$ & KP281451 & 588 & 99 \\
\hline UIZFSA-55 & Monacrosporium thaumasium & MTU51972 & U51972 & 549 & 99 \\
\hline UIZFSA-97 & Arthrobotrys brochopaga & ABU72609 & U72609 & 525 & 100 \\
\hline UIZFSA-97 & Arthrobotrys conoides & SBUG M12 & AF106534 & 549 & 99 \\
\hline UIZFSA-98 & Drechslerella brochopaga & $2 \mathrm{eA} 003$ & JF748753 & 493 & 100 \\
\hline UIZFSA-99 & Drechslerella brochopaga & 1eL002 & JF748752 & 494 & 100 \\
\hline$U I Z F S A-100$ & Arthrobotrys oligospora & AOZ1 & X94121 & 497 & 100 \\
\hline UIZFSA-101 & Arthrobotrys thaumasia & CBS 322.94 & AF106526 & 553 & 100 \\
\hline
\end{tabular}


649 Nematophagous fungi associated with the Moroccan olive nurseries surveyed.

\begin{tabular}{|c|c|c|c|c|c|c|c|}
\hline \multirow[t]{2}{*}{ Order } & \multirow[t]{2}{*}{ Family } & \multirow[t]{2}{*}{ Species } & \multirow{2}{*}{$\begin{array}{l}\text { Number } \\
\text { of strains }\end{array}$} & \multicolumn{4}{|c|}{ Region } \\
\hline & & & & Jbala & Guerouane & Haouz & Souss \\
\hline \multirow[t]{9}{*}{ Orbiliales } & \multirow[t]{9}{*}{ Orbiliaceae } & Arthrobotrys brochopaga & 2 & + & + & + & + \\
\hline & & A. conoides & 1 & - & + & - & + \\
\hline & & A. oligospora & 1 & - & + & - & - \\
\hline & & A. thaumasia & 3 & - & + & + & + \\
\hline & & A. scaphoides & 1 & + & + & + & + \\
\hline & & Dreschslerella brochopaga & 2 & - & + & - & + \\
\hline & & Dactylaria sp. & 1 & - & - & - & + \\
\hline & & Monacrosporium thaumasium & 5 & + & + & + & + \\
\hline & & M. microscaphoides & 1 & - & - & - & + \\
\hline \multirow[t]{2}{*}{ Eurotiales } & \multirow[t]{2}{*}{ Trichocomaceae } & Paecilomyces lilacinus & 36 & + & + & + & + \\
\hline & & Talaromyces assiutensis & 1 & - & - & - & + \\
\hline Agaricales & Pleurotaceae & Nematoctunus leiosporus & 1 & - & - & - & + \\
\hline Blastocladiales & Catenariaceae & Catenaria anguillulae & 1 & - & - & + & + \\
\hline Haptoglossales & Haptoglossaceae & Haptoglossa heterospora & 1 & - & - & - & + \\
\hline \multirow[t]{5}{*}{ Hypocreales } & Clavicipitaceae & Pochonia chlamydosporia & 4 & - & - & + & + \\
\hline & \multirow[t]{3}{*}{ Hypocreaceae } & Trichoderma asperellum & 4 & + & + & + & + \\
\hline & & T. harzianum & 3 & + & + & + & + \\
\hline & & T. longibrachiatum & 1 & + & + & + & + \\
\hline & Nectriaceae & Fusarium oxysporum & 4 & + & + & + & + \\
\hline
\end{tabular}
+: detected; -: not detected.

Table 5

Functional diversity of the nematophagous fungi ( $a$ - $d$ indicate significant groups, $P<0.05$ ).

654

\begin{tabular}{lccc}
\hline Region & $\begin{array}{c}\text { Samples with } \\
\text { NF }(\%)\end{array}$ & $\begin{array}{c}\text { Trapping } \\
\text { species }(\%)\end{array}$ & $\begin{array}{c}\text { Endoparasitic } \\
\text { species }(\%)\end{array}$ \\
\hline Jbala & $66.66 c$ & $7.13 d$ & 0 \\
Guerouane & $70.00 b$ & $25.12 b$ & $12.13 c$ \\
Haouz & $49.68 d$ & $24.39 c$ & $11.90 b$ \\
Souss & $70.90 a$ & $53.16 a$ & $25.80 a$ \\
\hline$P$-value & 0.000 & 0.000 & 0.000 \\
\hline
\end{tabular}




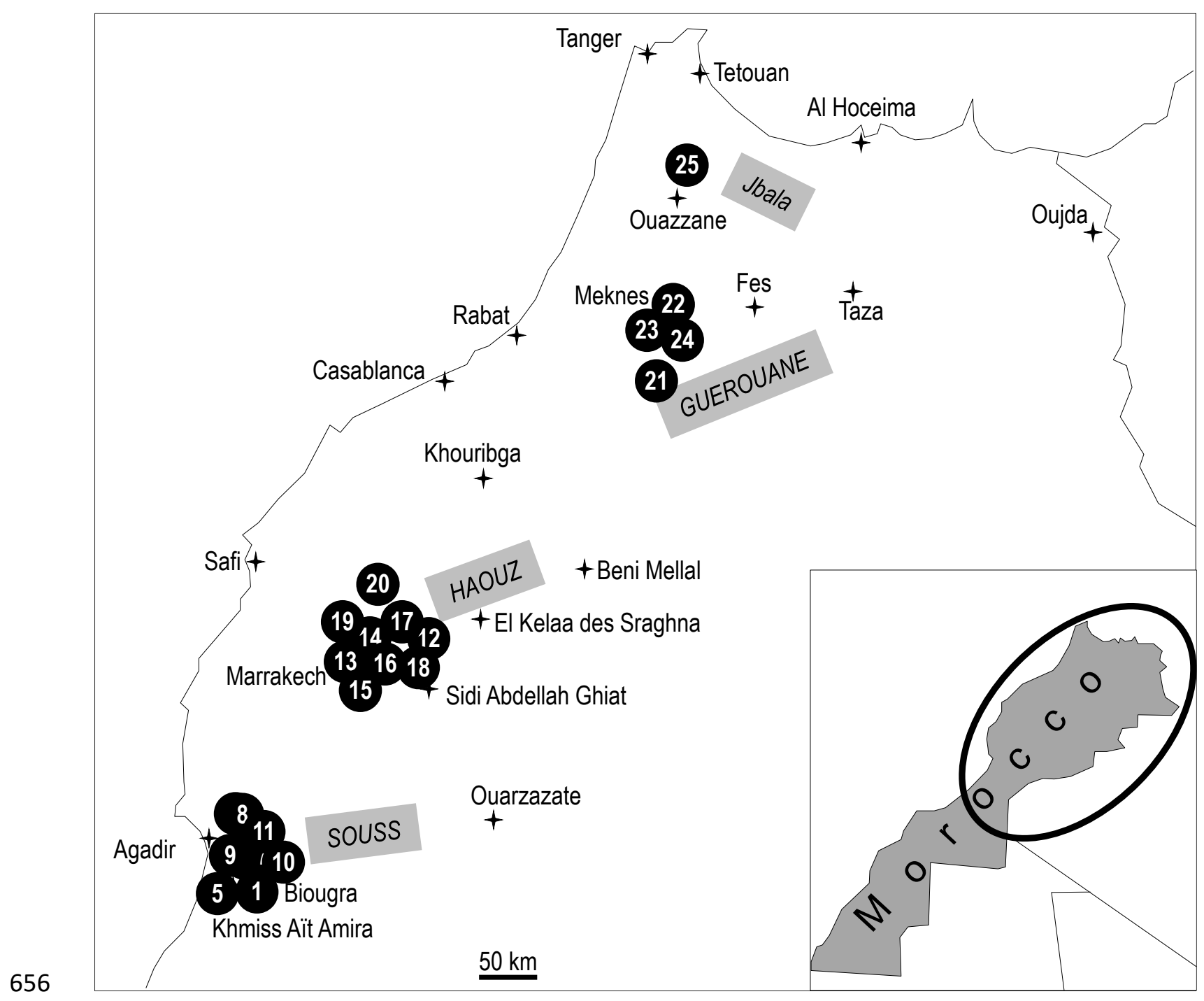

657 Figure 1. Distribution of the olive nurseries surveyed in Morocco. See Table 1 for more 658 information. 


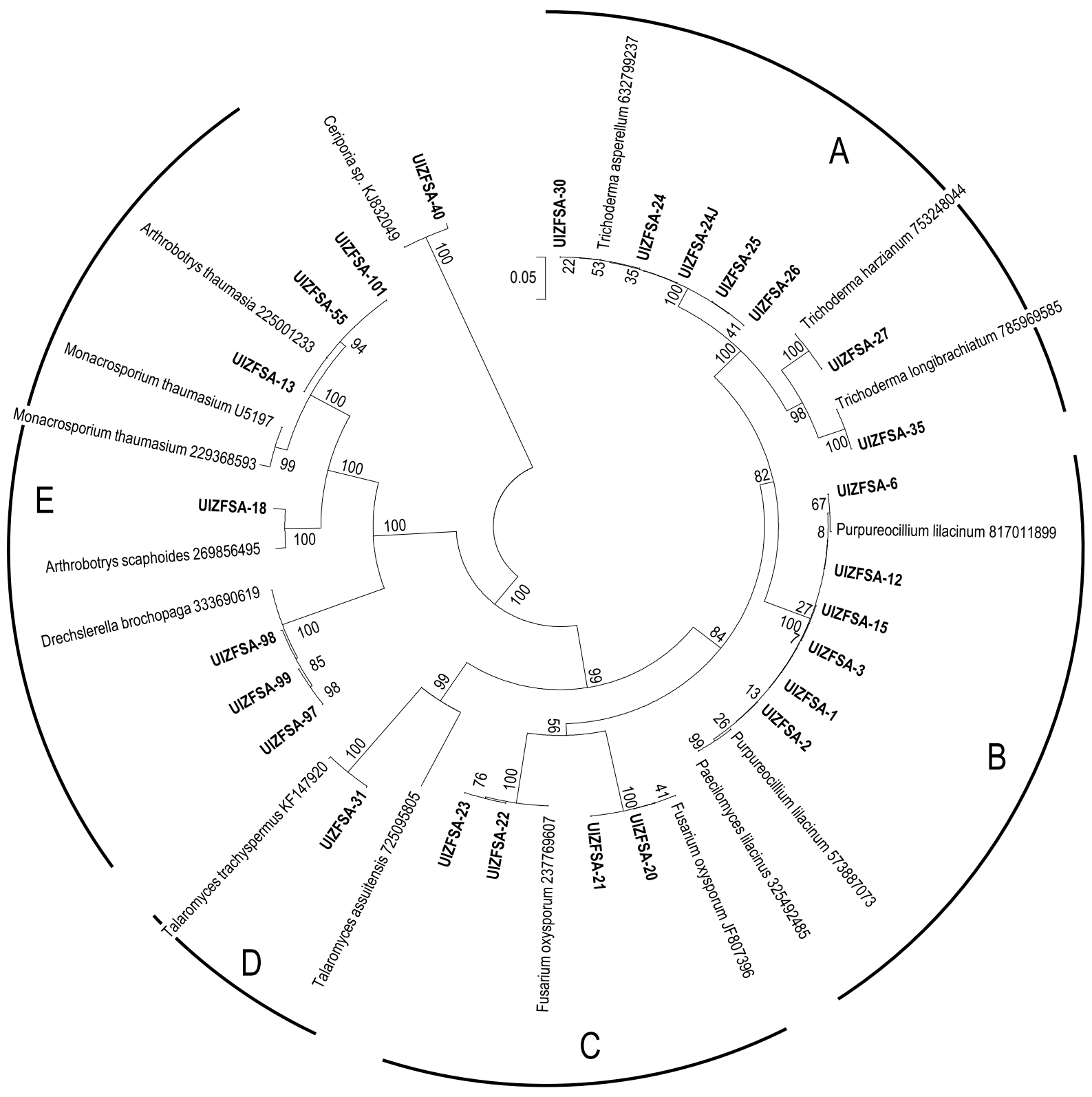

661 Figure 2. Neighbor-joining tree inferred from ITS rDNA sequences of the nematophagous

662 fungi isolated (in bold) and their closest GenBank matches (with accession numbers).

663 Bootstrap support values (1000 replicates) are provided as a percentage at the corresponding 664 nodes when $>50$. A to $\mathrm{E}=$ high similarity between phylogenetic groups. 

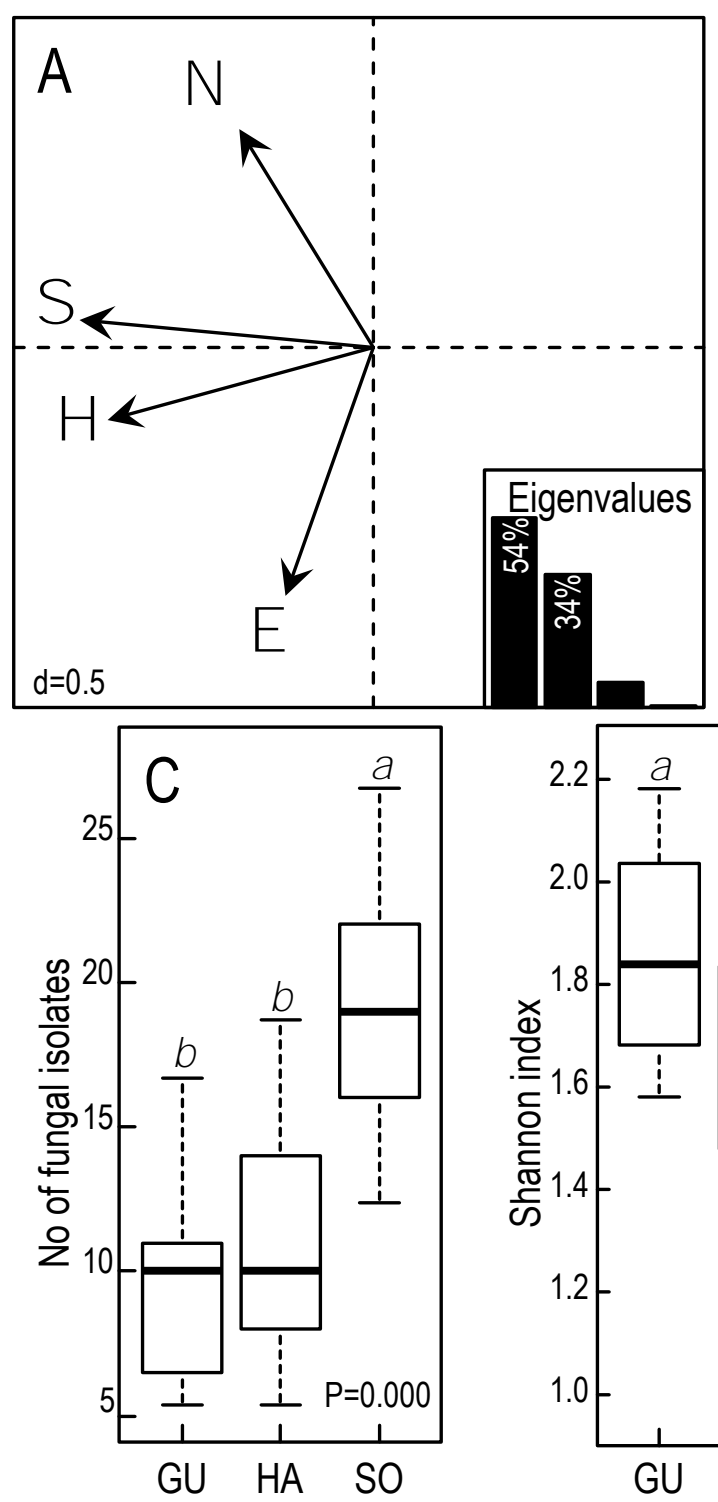
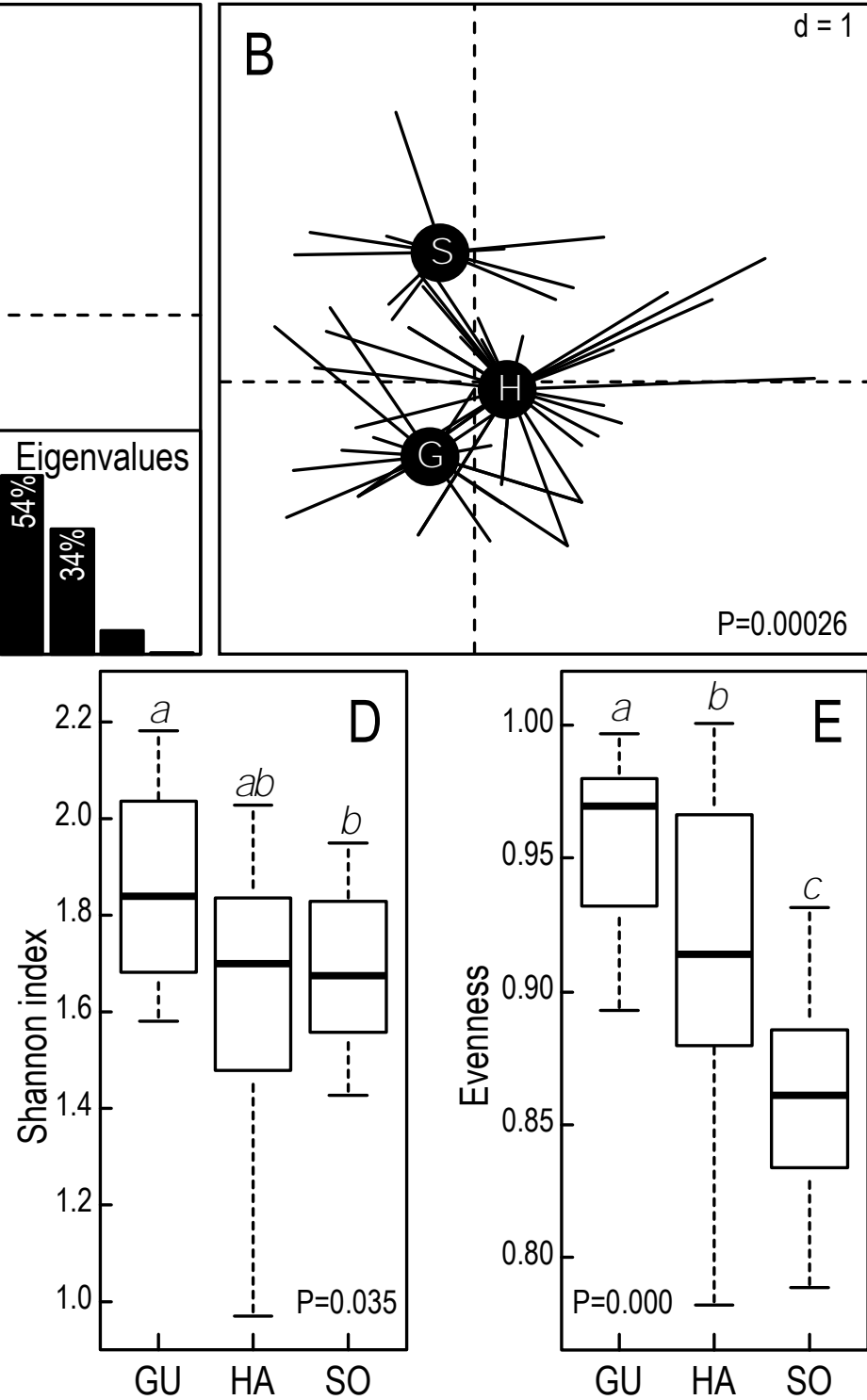

Figure 3. Diversity indices of the nematophagous fungus communities. (A) PCA loading plot

667 for the diversity indices in soil samples $(\mathrm{N}=$ a total number of fungal isolates; $\mathrm{S}=$ species

668 richness; $H^{\prime}=$ Shannon-Wiener diversity; $\mathrm{E}=$ species evenness). (B) Score plot for the 669 samples according to the region $(\mathrm{J}=\mathrm{Jbala} ; \mathrm{G}=$ Guerouane; $\mathrm{H}=$ Haouz; $\mathrm{S}=$ Souss $) .(\mathrm{C}, \mathrm{D}, \mathrm{E})$

$670 \mathrm{~N}, \mathrm{H}^{\prime}$ and E boxplots $(a-c$ indicate significant groups, $P<0.05)$.

671 


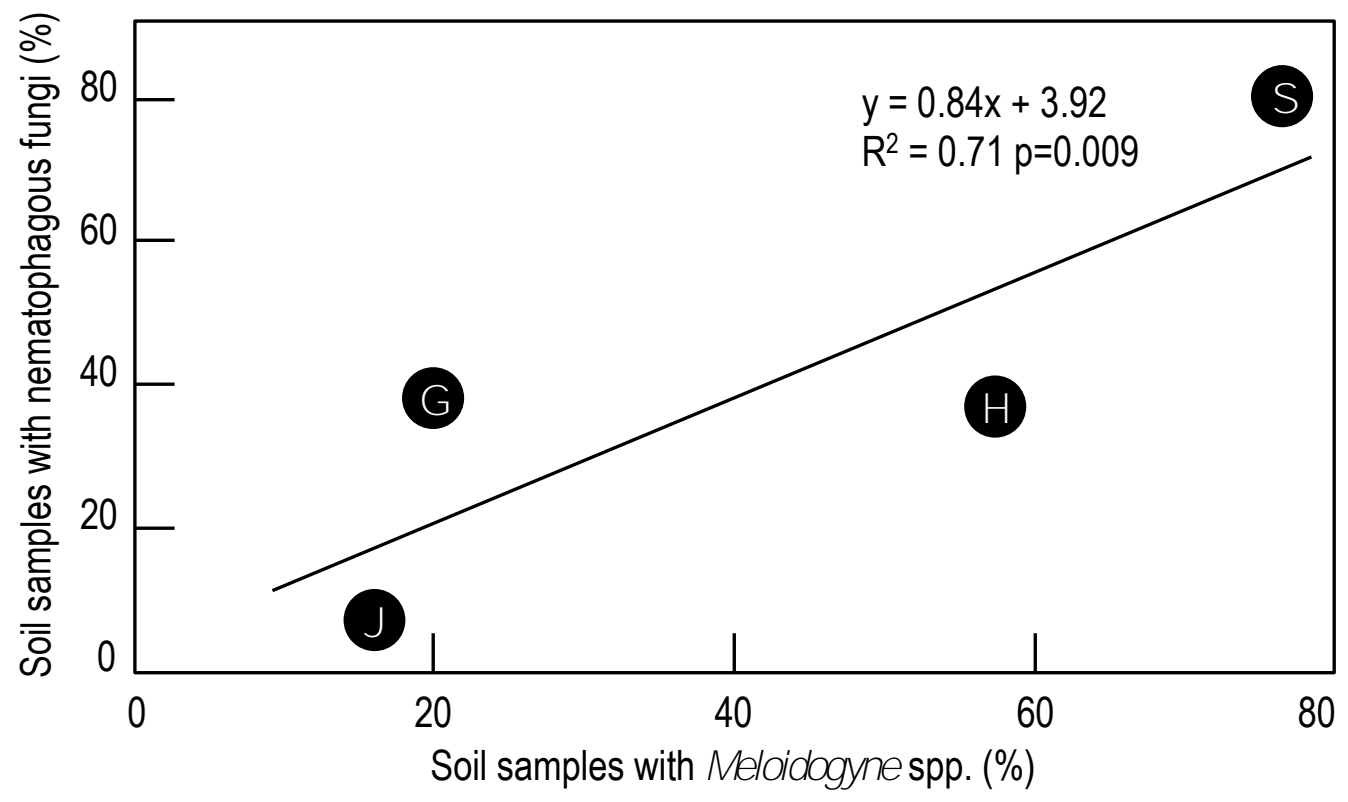

673

674 Figure 4. Rarefaction curve for root-knot nematodes (Meloidogyne spp.) and nematophagous

675 fungi detected in the olive nurseries according to the regions $(\mathrm{J}=\mathrm{Jbala} ; \mathrm{G}=$ Guerouane; $\mathrm{H}=$ 676 Haouz; $\mathrm{S}=$ Souss).

677

678

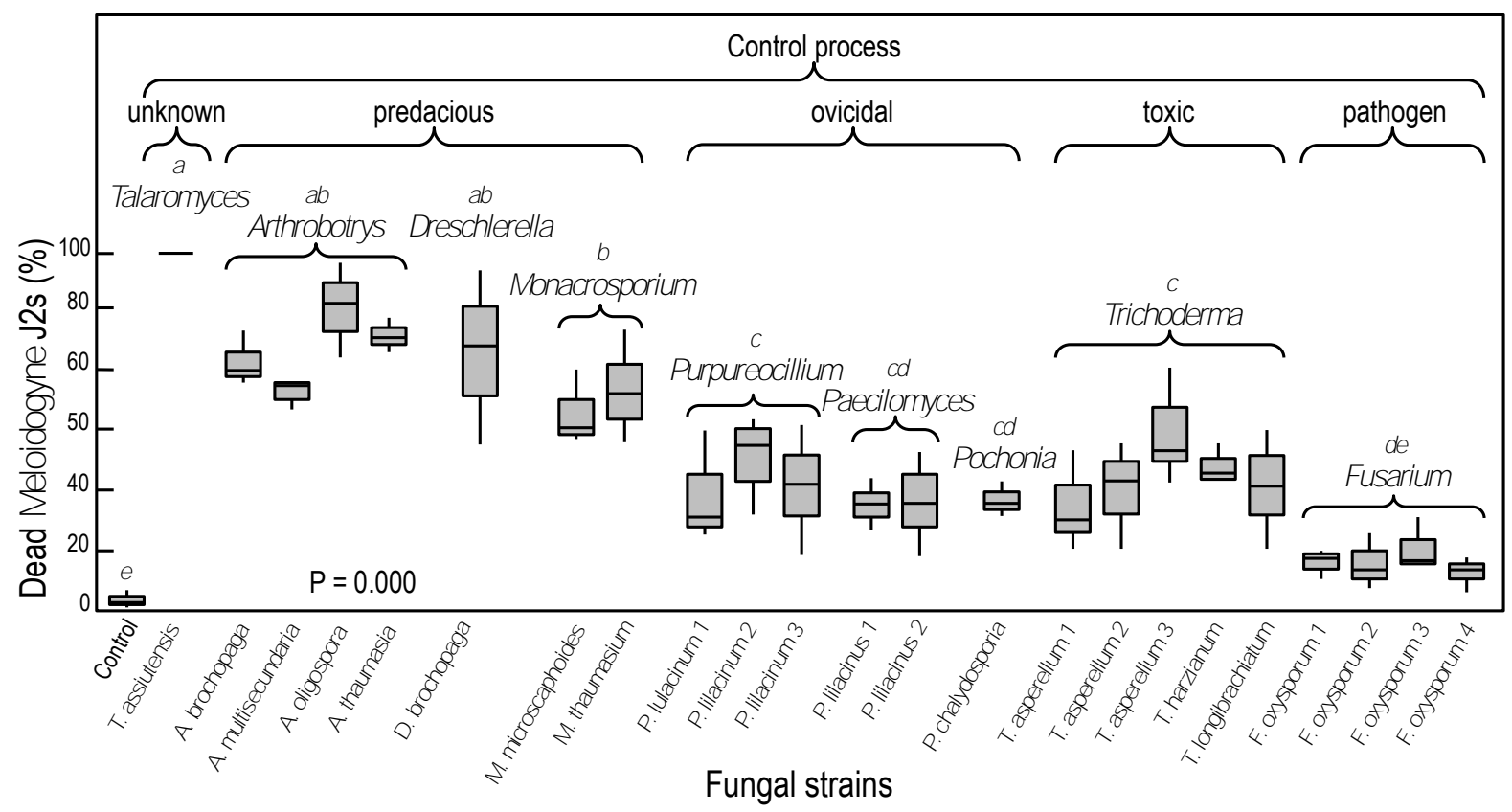

679 Figure 5. In vitro efficiency of nematophagous fungal stains: percentage of dead M. javanica 680 juveniles $(a-e$ indicate significant groups, $P<0.05)$. 